\title{
DNMT3B (C46359T) Polymorphisms and Immunoexpression of DNMT3b and DNMT1 Proteins in Oral Lichen Planus
}

\author{
Thiago Fonseca-Silva ${ }^{a}$ Marcos Vinícius Macedo de Oliveira ${ }^{a}$ Carlos Alberto de Carvalho Fraga ${ }^{a}$ \\ Lucyana Conceição Farias ${ }^{a}$ b Érika Patrícia Pereira Gomes ${ }^{a}$ Lucas Oliveira Barros ${ }^{a}$ \\ Ashbeel Roy ${ }^{c}$ Ricardo Santiago Gomez ${ }^{b}$ Alfredo Maurício Batista De Paula ${ }^{a}$ \\ André Luiz Sena Guimarães ${ }^{a}$
}

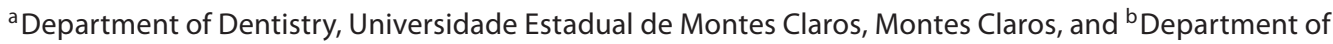
Oral Pathology and Surgery, Universidade Federal de Minas Gerais, Belo Horizonte, Brazil; ' ${ }^{\circ}$ Department of Physiology and Pharmacology, Schulich School of Medicine and Dentistry, University of Western Ontario, London, Ont., Canada

\section{Key Words}

Oral lichen planus $\cdot$ Oral inflammatory fibrous hyperplasia $\cdot$

DNA methylation - DNMT3b polymorphism

\begin{abstract}
Objective: To investigate the DNMT3B (C46359T) polymorphism and immunoexpression of DNMT3b and DNMT1 in oral lichen planus (OLP) compared to a control group. Methods: We aimed to investigate the DNMT3B (C46359T) polymorphism and immunoexpression of DNMT3b and DNMT1 in OLP ( $n=32)$, comparing it with oral mucosa (control; $n=$ 24). The DNMT3B (C46359T) polymorphism was analyzed using the RFLP-PCR and DNMT1, and DNMT3a proteins were identified using immunohistochemistry. We also compared the DNMT3B expression in OLP and oral inflammatory fibrous hyperplasia (OIFH), another oral inflammatory disease. Differences between the groups were determined by specific statistical analyses. Results: The CT genotype of DNMT3B was associated with OLP development $(p=0.012)$. Increased expression of DNMT3B and DNMT1 was observed in OLP compared to the control group $(p=0.014$ and $p=$ 0.001 , respectively). A significant increase in DNMT3B protein levels was observed in the genotype CT in DNMT3B
\end{abstract}

(C46359T) polymorphisms $(p=0.045)$. No DNMT3B expression differences between OLP and OIFH were observed. Conclusions: Our data show that the DNMT3B (C46359T) polymorphism is associated with OLP development. Furthermore, increased expression of the enzyme DNMT3B, an epigenetic-associated protein, is present in OLP.

Copyright $\odot 2012$ S. Karger AG, Basel

\section{Introduction}

Oral lichen planus (OLP) is a chronic inflammatory oral disease, the etiology of which is unknown but appears to be related to a cell-mediated immune process involving $\mathrm{T}$ lymphocyte aggression targeted to the basal layer of the oral mucosa [1-3]. The disease is more common in the female population and is most often seen in adults while rarely diagnosed in children $[4,5]$. OLP may occur at any site of an oral cavity, but the oral mucosa, tongue and gingiva are more commonly affected sites. Clinically, the disease can manifest in several different forms: reticular (white lesions), erythematous (atrophic) and erosive (ulcerated, bullous) [3, 6, 7]. Evidence suggests that OLP is associated with an increased risk of de-

André Luiz Sena Guimarães

Universidade Estadual de Montes Claros, Hospital Universitário Clemente de Faria

Laboratório de Pesquisa em Saúde, Avenida Cula Mangabeira, 562

Montes Claros, Minas Gerais 39401-001 (Brasil)

Tel. +55 383224 8327, E-Mail andreluizguimaraes@gmail.com 
veloping cancer [8-10]. Although a number of studies have analyzed the malignant transformation of OLP, the specific process of malignization remains controversial [11-15]. Oral inflammatory fibrous hyperplasia (OIFH) is when reactive lesions appear, resulting from chronic oral irritation due to the use of poorly adapted dentures. Microscopically, OIFH consists of connective tissue characterized by collagen deposition and chronic inflammatory infiltration according to the stage of its development [16]. It was demonstrated that OIFH samples have similar characteristics to those observed in chronic inflammatory lesions [17].

Epigenetic modifications are phenomena that act nonspecifically on DNA and can generate changes in the expression of any gene [18]. DNA methylation is the addition of methyl radicals to specific regions of DNA containing, predominantly, cytosine nucleotides. It is catalyzed by a family of enzymes denominated DNA methyltransferases (DNMTs), including three catalytically active enzymes - DNMT1, DNMT3a and DNMT3b [19-22]. DNMT3a and DNMT3b are responsible for de novo methylation and play an important role in controlling gene activity, embryonic development and genomic imprinting, while DNMT1 is an enzyme of maintenance and is thus involved in the establishment of a new methylation pattern $[23,24]$.

Although the functional effects of DNMT3B polymorphisms have not been elucidated, several studies have previously shown that they may affect DNMT3b protein activity during DNA methylation. It was reported that the single-nucleotide polymorphism SNP-149C $\rightarrow \mathrm{T}$ in the promoter region of the DNMT3B gene was significantly associated with both higher promoter activity of the DNMT3b protein and a predisposition to aberrant methylation [25-27]. Given these previously published data, we attempted to analyze the DNMT3B (C46359T) polymorphisms and the expression of DNMT3b and DNMT1 proteins in OLP compared with the control. Moreover, we attempted to verify whether this DNMT3B (C46359T) polymorphism was associated with DNMT3b protein expression in OLP samples.

\section{Patients and Methods}

\section{Study Design and Tissue Specimens}

This cross-sectional study was performed on archived tissue blocks from surgically resected specimens of OLP ( $n=32$; maleto-female ratio $=1: 1.9$; mean age $=53.47 \pm 3.60$ years) and a control group $(\mathrm{n}=24$; male-to-female ratio $1: 1.4$; mean age $=32.83$ years; SD 15.78 years; range 15-74 years). Mucocele samples were used as a control group. We also compared DNMT3B expression with OIFH as a chronic inflammatory lesion $(\mathrm{n}=8$; male-to-female ratio $=1: 0.6$; mean age $=48.8 \pm 9.8$ ). Data related to patients and samples were obtained from the Department of Dentistry at the State University of Montes Claros, Minas Gerais, Brazil. All patients were from the same geographical area, but description of skin color was not used because, in Brazil, it is a poor predictor of genomic ancestry [28]. The diagnoses of patients presenting OLP lesions were confirmed by clinical examination and histopathological evaluation [29]. Ethical approval for this study was obtained from the relevant local ethics committees (Unimontes/ Coep-1133/2008).

\section{DNMT3B Genotypes}

DNA was isolated from ten $10-\mu \mathrm{m}$-thick tissue sections from each tissue block of OLP specimens using the DNeasy Tissue Kit (Qiagen, Chatsworth, Calif., USA) as previously described [25].

DNMT3B (C46359T) polymorphism was assessed by RFLP with specific primers (forward $5^{\prime}$-TGGCTACCAGGTCTCCTTGGCC-3'; 5'-GGTAGCCGGGAACTCCACGG-3') [25]. Polymerase chain reaction for DNMT3B was performed in a total volume of $25 \mu$ l containing approximately $100 \mathrm{ng}$ of genomic DNA template, $0.5 \mu \mathrm{l}$ of each primer $(20 \mathrm{pmol} / \mu \mathrm{l}), 2.5 \mu \mathrm{ldNTP} \operatorname{mix}(25$ $\mathrm{mM}$ of each; AMRESCO, USA), $2.5 \mu \mathrm{l} 10 \times$ PCR buffer, $1.25 \mu \mathrm{l}$ magnesium chloride (50 mM), and $2.5 \mathrm{U}$ of platinum Taq DNA polymerase (Invitrogen Life Technologies, USA). The 230-bp PCR product from the DNMT3B gene was digested with the $B \ln \mathrm{I}$ restriction endonuclease (Sigma-Aldrich, USA), which recognizes a restriction site (C/CTAGG) in the T allele but not the wild-type $\mathrm{C}$ allele which lacks the $B \ln \mathrm{I}$ restriction site. Thus, the wild-type $\mathrm{C}$ allele has only one band $(230 \mathrm{bp})$, while the polymorphic $\mathrm{T}$ allele has two bands (172 and $58 \mathrm{bp}$ ). For this, $10 \mu \mathrm{l}$ of amplified DNA was digested with $2.5 \mathrm{U}$ of $\mathrm{B} \ln \mathrm{I}$ for $16 \mathrm{~h}$ at $37^{\circ} \mathrm{C}$. PCR and restriction reactions were performed in a thermocycler (Eppendorf $A G$, Hamburg, Germany) and the PCR products were verified on a $6.5 \%$ polyacrylamide gel. DNA sequencing was performed to confirm the DNMT3B genotyping as determined by PCR-RFLP. All cases were classified according to the distribution of the genotypic polymorphisms for the DNMT3B gene (CC, CT, TT).

\section{Immunohistochemical Analyses}

For the immunohistochemical reactions, $3-\mu \mathrm{m}$-thick sections were mounted on organosilane-coated slides. Primary mouse monoclonal antibodies were used against DNMT3B (clone 52A1018, Imgenex, USA) and DNMT1 (clone 60B1220.1, 1:250, Imgenex). Antibodies were detected with the aid of an LSAB ${ }^{\mathrm{TM}}$ visualization kit (cat. No. K0690; Dako, Denmark) employing the chromogen diaminobenzidine for color development. Slides were finally counterstained with Mayer's hematoxylin and mounted. Negative controls were obtained by substituting the primary antibodies for normal whole rabbit serum (cat. No. X0902; Dako). A sample of oral carcinoma (previously shown to be strongly positive for the antibodies investigated) served as a positive control. Only cells that exhibited brown cytoplasmic or nuclear staining were considered positive.

Immunohistochemical Analysis

The immunohistochemical expression was evaluated using an Olympus ${ }^{\circledR} \mathrm{BH} 2$ microscope $(10 \times$ ocular and $40 \times$ objective lenses), and an ocular lattice (area $0.092 \mathrm{~mm}^{2}$ ) with 100 points com- 
posed of 10 horizontal and 10 vertical test lines superimposed on the test field that was to be measured. A total area of $1.84 \mathrm{~mm}^{2}$ was evaluated for each of the samples. Immunohistochemical analysis of DNMT1 and DNMT3b proteins was performed by obtaining a percentage of positive-staining cells in 20 microscopic fields (for each specimen).

\section{Statistical Analysis}

Results of protein expression were expressed as mean \pm SD. Analysis of the (C46359T) polymorphisms in the control and the OLP were performed by $\chi^{2}$ test with the Fisher and Pearson exact tests. The Kolmogorov-Smirnov test was used to determine whether the distribution of continuous variables was normal. Analysis of tissue immunolocalization of DNMT3b and DNMT1 assumed nonparametrical distribution and comparison between groups was done using the Mann-Whitney and Kruskal-Wallis statistical tests. All analyses were performed using SPSS 17.0 (SPSS Inc., USA) and statistical significance was set at $\mathrm{p}<0.05$. The concordance values obtained (OLP samples, $\kappa=0.866, p<$ 0.05 ) revealed good agreement.

\section{Results}

The impact of the DNMT3B polymorphism on the protein levels was evaluated with the Kruskal-Wallis test that showed a significant increase in DNMT3B protein levels associated with T allele (table 1).

The immunolocalization of DNMT3b and DNMT1 and the polymorphisms of the DNMT3B gene are shown in figure 1. Tissue expression of DNMT3b and DNMT1 were frequently noted in the basal and parabasal layers of all samples. However, this expression consistently demonstrated strong nuclear staining from the basal layer to the surface epithelium in the majority of the OLP cases. A higher tissue expression of DNMT3b $(p=0.0140)$ and DNMT1 $(\mathrm{p}<0.0010)$ was noted in the OLP compared to the control (fig. 1; table 2). No differences in DNMT3B expression between LP and OIFH were observed (fig. 1). We also compared molecular features and clinical data (table 3), but no association between these factors was observed.

\section{Discussion}

Even with the increasing number of studies in the field of epigenetics, the clinical significance of these alterations in gene expression has not yet been established. DNA methylation is characterized by both the focal modification of gene-associated $\mathrm{CpG}$ islands and generalized genome-wide reduction in 5-methylcytosine, both of which are seen in various oral lesions, including cancer
Table 1. Association between the DNMT3B polymorphism and the expression of DNMT3B proteins in OLP and normal oral mucosa

\begin{tabular}{llll}
\hline Parameters & \multicolumn{2}{c}{ DNMT3B polymorphism } & \\
\cline { 2 - 4 } & CC & CT & TT \\
\hline Lesions & & \\
$\quad$ OLP & $6(18.8 \%)$ & $19(59.4 \%)$ & $7(21.9 \%)$ \\
$\quad \begin{array}{l}\text { Oral mucosa } \\
\text { p value }\end{array}$ & $13(54.2 \%)$ & $10(41.7 \%)$ & $1(4.2 \%)$ \\
$\begin{array}{l}\text { Immunohistochemistry - mean } \\
\quad \text { DNMT3B }\end{array}$ & $\mathbf{0 . 0 1 2}$ & \\
$\quad$ p value & 20.47 & 30.89 & 32.75 \\
\hline
\end{tabular}

Significant $\mathrm{p}$ value $<0.05$ is in bold.

Analyzed by $\chi^{2}$ and the Kruskal-Wallis test.

Table 2. Association between different samples and expression of DNMT3B and DNMT1 proteins

\begin{tabular}{llll}
\hline & \multicolumn{3}{c}{ Lesions } \\
\cline { 2 - 4 } & OLP & oral mucosa & p value \\
\hline Immunohistochemistry - mean & & \\
DNMT3B & 31.75 & 21.32 & $\mathbf{0 . 0 1 4}$ \\
DNMT1 & 35.63 & 14.05 & $\mathbf{0 . 0 0 0}$ \\
\hline
\end{tabular}

Significant $\mathrm{p}$ value $<0.05$ is in bold.

Analyzed by the Mann-Whitney test.

and premalignant lesions $[19,25,30]$. This process can lead to a conformational change in the DNA and consequently generate modifications in the pattern of gene expression and silencing genetics [21,31,32].

Several studies suggest that the increased expression of DNA methyltransferases is associated with a predisposition to aberrant DNA methylation and, consequently, a change in gene expression [24, 33-35]. DNMT3b and DNMT1 proteins have been associated with the hypermethylation of several genes, many of which are related to processes associated with immunologically mediated diseases [36, 37].

In this study, we observed an increased expression of DNMT3b and DNMT1 in OLP when compared with control samples. Several studies have shown that DNA methylation regulates the expression of many different genes involved in the cell cycle and can, therefore, influence events pertaining to immunological disease $[31,36$, 

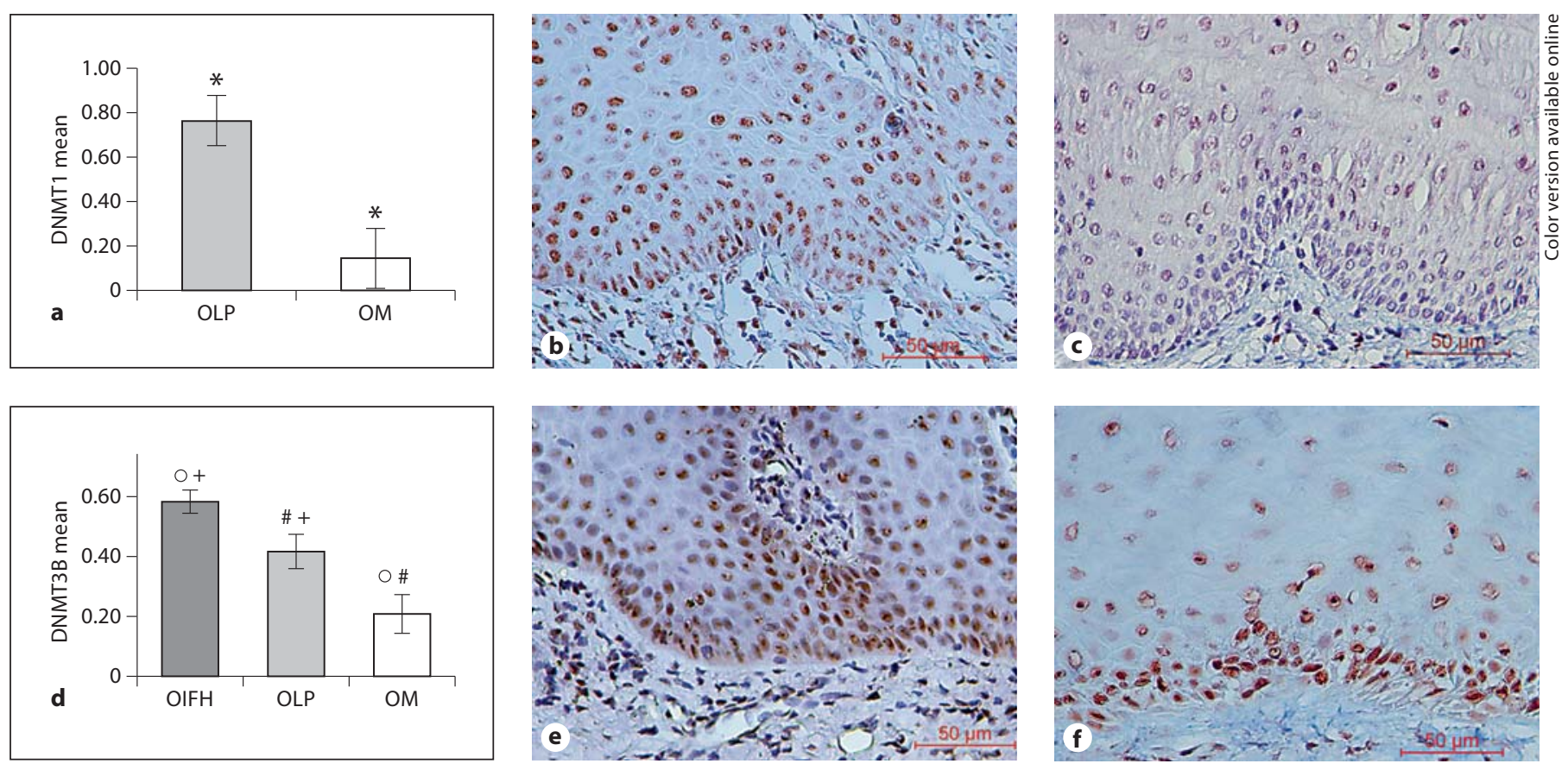

Fig. 1. Increased expression of DNMT1 protein (a) was found in OLP (b) compared to the control (c). ${ }^{*} \mathrm{p}=0.014$. $\mathbf{d}$ Higher expression of DNMT3b expression in OLP (e) and OIFH (g) compared to normal oral mucosa $(\mathrm{OM})(\mathbf{f}){ }^{\#} \mathrm{p}=0.014$ and ${ }^{\circ} \mathrm{p}=$ 0.010 , respectively. No significant differences between OLP and OIFH were observed $\left({ }^{+} \mathrm{p}=0.228\right)$.

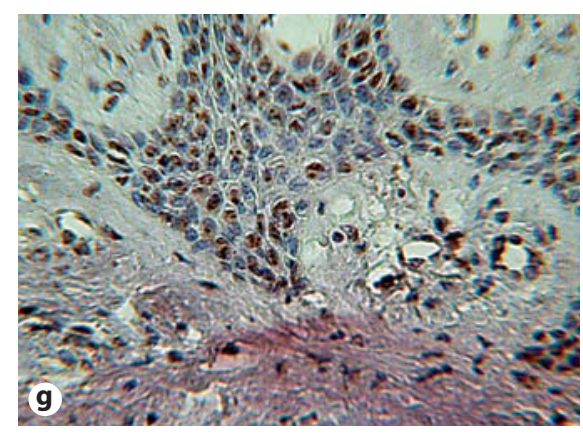

37]. Our data suggest that increased expression of these proteins in OLP may be related to DNA methylation events which consequently change the expression of several genes related to the immune response.

Single-nucleotide polymorphism (SNP) has been demonstrated in a vast majority of oral diseases $[5,38-41]$ and especially OLP [41-43]. It was postulated that the presence of the T allele increases DNMT3B protein expression and this leads to an increase in aberrant de novo methylation of CpG islands in some genes [35, 44]. Recently, various studies have shown that some SNPs in the DNMT3B gene may influence DNMT3b DNA methylation activity and might be associated with immunologically mediated diseases [44-47]. We showed that the CT genotype of the DNMT3B (C46359T) polymorphism was associated with OLP and, interestingly, this genotype was also associated with an increase in DNMT3B protein ex- pression. A potential link among DNMT3B SNP, linked disequilibrium and the cytokine level might be involved in OLP or inflammation [41, 48]. In our previous study, we demonstrated that the T allele of DNMT3B genotype was significantly associated with advanced TNM staging and tumor size in older patients with head and neck cancer [25]. This fact may be associated with the malignant transformation of some cases of OLP.

Taken together, these data suggest that the DNMT3B (C46359T) polymorphism could alter the pattern of de novo DNA methylation due to increased expression of the DNMT3b protein and therefore influence the expression of genes related to OLP. Thus, DNA methylation in OLP seems to be a major event that may be related to the development of this lesion. Additionally, altered DNA methylation may also be associated with the malignant transformation of OLP, an idea supported by the 
Table 3. Association between molecular features and clinical OLP

\begin{tabular}{|c|c|c|c|c|c|c|c|c|}
\hline \multirow[t]{2}{*}{ Parameters } & \multicolumn{2}{|l|}{ Gender } & \multicolumn{2}{|l|}{ Age } & \multicolumn{2}{|c|}{ Clinical characteristics } & \multicolumn{2}{|l|}{ Lesion site } \\
\hline & male & female & $\leq 45$ years & $\geq 46$ years & reticular & atrophic/erosive & $\mathrm{BM} / \mathrm{RTM} / \mathrm{T}$ & $\mathrm{P} / \mathrm{FM}$ \\
\hline \multicolumn{9}{|c|}{ DNMT3B polymorphism } \\
\hline CC & $3(50.0)$ & $3(50.0)$ & $4(66.7)$ & $2(33.3)$ & $6(100)$ & 0 & $5(83.3)$ & $1(16.7)$ \\
\hline $\mathrm{CT}$ & $6(31.6)$ & $13(68.4)$ & $7(36.8)$ & $12(63.2)$ & $15(78.9)$ & $4(21.1)$ & $16(84.2)$ & $3(15.8)$ \\
\hline $\mathrm{TT}$ & $2(28.6)$ & $5(71.4)$ & $4(57.1)$ & $3(42.9)$ & $6(85.7)$ & $1(14.3)$ & $6(85.7)$ & $1(24.3)$ \\
\hline $\mathrm{p}$ value & \multicolumn{2}{|c|}{0.664} & \multicolumn{2}{|c|}{0.366} & \multicolumn{2}{|c|}{0.462} & \multicolumn{2}{|c|}{0.993} \\
\hline \multicolumn{9}{|c|}{ Immunohistochemistry - mean } \\
\hline DNMT3B & 17.14 & 16.17 & 14.33 & 18.41 & 16.15 & 18.40 & 16.74 & 15.20 \\
\hline $\mathrm{p}$ value & \multicolumn{2}{|c|}{0.785} & \multicolumn{2}{|c|}{0.230} & \multicolumn{2}{|c|}{0.650} & \multicolumn{2}{|c|}{0.763} \\
\hline \multicolumn{9}{|c|}{ Mucocele analysis } \\
\hline \multicolumn{9}{|c|}{ DNMT3B polymorphism } \\
\hline $\mathrm{CC}$ & $3(23.1)$ & $10(76.9)$ & $12(92.3)$ & $1(7.7)$ & - & - & - & - \\
\hline CT & $6(60.0)$ & $4(40.0)$ & $7(70.0)$ & $3(30.0)$ & - & - & - & - \\
\hline TT & $1(100.0)$ & 0 & 0 & $1(100.0)$ & - & - & - & - \\
\hline $\mathrm{p}$ value & \multicolumn{2}{|c|}{0.035} & \multicolumn{2}{|c|}{0.033} & - & & - & \\
\hline \multicolumn{9}{|c|}{ Immunohistochemistry - mean } \\
\hline DNMT3B & 13.11 & 10.38 & 11.06 & 13.50 & - & - & - & - \\
\hline $\mathrm{p}$ value & \multicolumn{2}{|c|}{0.357} & \multicolumn{2}{|c|}{0.538} & - & & - & \\
\hline \multicolumn{9}{|c|}{ Hyperplasia analysis } \\
\hline \multicolumn{9}{|c|}{ DNMT3B polymorphism } \\
\hline $\mathrm{CC}$ & - & - & - & - & - & - & - & - \\
\hline CT & - & - & - & - & - & - & - & - \\
\hline TT & - & - & - & - & - & - & - & - \\
\hline $\mathrm{p}$ value & - & & - & & - & & - & \\
\hline \multicolumn{9}{|c|}{ Immunohistochemistry - mean } \\
\hline DNMT3B & 5.33 & 4.00 & 4.00 & 4.80 & - & - & - & - \\
\hline $\mathrm{p}$ value & \multicolumn{2}{|c|}{0.571} & \multicolumn{2}{|c|}{0.786} & - & & - & \\
\hline
\end{tabular}

Values in parentheses are percentages. Significant $\mathrm{p}$ value $<0.05$ is in bold. Analyzed by $\chi^{2}$ and the Mann-Whitney test. $\mathrm{BM}=$ Buccal mucosa; RTM = retro-molar trigone mucosa; $\mathrm{T}=$ tongue; $\mathrm{P}=$ palate; $\mathrm{FM}=$ floor of mouth.

previously observed link between $p 16_{C D K N 2 A}$ methylation imbalance and oral carcinogenesis [19]. This assumption, however, needs to be demonstrated by further studies.

In conclusion, our data show that DNMT3B (C46359T) polymorphism is associated with the development of OLP. Furthermore, increased expression of the enzyme DNMT3B, an epigenetic-associated protein, is present in OLP.

\section{Acknowledgements}

This study was supported by grants from Conselho Nacional de Desenvolvimento Científico e Tecnológico (CNPq) and Fundação de Amparo a Pesquisa do Estado de Minas Gerais (FAPEMIG). Dr. Guimarães and Dr. Gomez are research fellows of CNPq. Dr. De Paula is a research fellow of FAPEMIG.
References

\section{2} tren D. The clinical manifestations and Clin 2003;21:79-89.

-3 Sousa FA, Rosa LE: Oral lichen planus: clinical and histopathological considerations. Braz J Otorhinolaryngol 2008;74:284-292.

-4 Mollaoglu N: Oral lichen planus: a review. $\mathrm{Br}$ J Oral Maxillofac Surg 2000;38:370-377.

$\checkmark 5$ Perdigao PF, Guimaraes AL, Victoria JM, Xavier GM, Romano-Silva MA, Gomez RS: Serotonin transporter gene polymorphism (5-HTTLPR) in patients with oral lichen planus. Arch Oral Biol 2007;52:889-893.

6 Eisen D: The clinical features, malignant potential, and systemic associations of oral lichen planus: a study of 723 patients. J Am Acad Dermatol 2002;46:207-214.

7 Jungell P: Oral lichen planus: a review. Int J Oral Maxillofac Surg 1991;20:129-135. 
-8 Fang M, Zhang W, Chen Y, He Z: Malignant transformation of oral lichen planus: a retrospective study of 23 cases. Quintessence Int 2009;40:235-242.

$>9$ Szarka K, Tar I, Feher E, Gall T, Kis A, Toth ED, Boda R, Marton I, Gergely L: Progressive increase of human papillomavirus carriage rates in potentially malignant and malignant oral disorders with increasing malignant potential. Oral Microbiol Immunol 2009;24: 314-318.

10 Yarom N, Shani T, Amariglio N, Taicher S, Kaplan I, Vered M, Rechavi G, Trakhtenbrot L, Hirshberg A: Chromosomal numerical aberrations in oral lichen planus. J Dent Res 2009;88:427-432.

$\checkmark 11$ Epstein JB, Wan LS, Gorsky M, Zhang L: Oral lichen planus: progress in understanding its malignant potential and the implications for clinical management. Oral Surg Oral Med Oral Pathol Oral Radiol Endod 2003;96:32-37.

-12 Gonzalez-Moles MA, Scully C, Gil-Montoya JA: Oral lichen planus: controversies surrounding malignant transformation. Oral Dis 2008; 14:229-243.

-13 Lanfranchi-Tizeira HE, Aguas SC, Sano SM: Malignant transformation of atypical oral lichen planus: a review of 32 cases. Med Oral 2003;8:2-9.

14 Larsson A, Warfvinge G: Malignant transformation of oral lichen planus. Oral Onco 2003;39:630-631.

-15 Mignogna MD, Fedele S, Lo Russo L, Mignogna C, de Rosa G, Porter SR: Field cancerization in oral lichen planus. Eur J Surg Oncol 2007;33:383-389.

16 Magnusson BC, Rasmusson LG: The giant cell fibroma: a review of 103 cases with immunohistochemical findings. Acta Odontol Scand 1995;53:293-296.

- 17 Santos PP, Nonaka CF, Pinto LP, de Souza LB: Immunohistochemical expression of mast cell tryptase in giant cell fibroma and inflammatory fibrous hyperplasia of the oral mucosa. Arch Oral Biol 2011;56:231-237.

18 Guz J, Foksinski M, Olinski R: Mechanism of DNA methylation and demethylation - its role in control of genes expression (in Polish). Postepy Biochem 2010;56:7-15.

19 Cao J, Zhou J, Gao Y, Gu L, Meng H, Liu H, Deng D: Methylation of p16 CpG island associated with malignant progression of oral epithelial dysplasia: a prospective cohort study. Clin Cancer Res 2009;15:5178-5183.

20 Ducasse M, Brown MA: Epigenetic aberrations and cancer. Mol Cancer 2006;5:60.

-21 Fazzari MJ, Greally JM: Epigenomics: beyond CpG islands. Nat Rev Genet 2004;5: 446-455.

-22 Singal R, Ginder GD: DNA methylation. Blood 1999;93:4059-4070.

-23 Bestor TH: The DNA methyltransferases of mammals. Hum Mol Genet 2000;9:23952402 .
24 Girault I, Tozlu S, Lidereau R, Bieche I: Expression analysis of DNA methyltransferases $1,3 \mathrm{a}$, and $3 \mathrm{~b}$ in sporadic breast carcinomas. Clin Cancer Res 2003;9:4415-4422.

25 Farias LC, Fraga CA, De Oliveira MV, Silva TF, Marques-Silva L, Moreira PR, De-Paula AM, Gomez RS, Guimaraes AL: Effect of age on the association between p16CDKN2A methylation and DNMT3B polymorphism in head and neck carcinoma and patient survival. Int J Oncol 2010;37:167-176.

26 Montgomery KG, Liu MC, Eccles DM, Campbell IG: The DNMT3B C $\rightarrow$ T promoter polymorphism and risk of breast cancer in a British population: a case-control study. Breast Cancer Res 2004;6:R390-394.

27 Singal R, Das PM, Manoharan M, Reis IM, Schlesselman JJ: Polymorphisms in the DNA methyltransferase $3 \mathrm{~b}$ gene and prostate cancer risk. Oncol Rep 2005; 14:569-573.

28 Parra FC, Amado RC, Lambertucci JR, Rocha J, Antunes CM, Pena SD: Color and genomic ancestry in Brazilians. Proc Natl Acad Sci USA 2003;100:177-182.

29 Scully C, Carrozzo M: Oral mucosal disease: lichen planus. Br J Oral Maxillofac Surg 2008;46:15-21.

30 Liu HW, Hu BQ, Cao CF: The p16 methylation in oral leukoplakia and oral squamous cell carcinoma (in Chinese). Zhonghua Kou Qiang Yi Xue Za Zhi 2005;40:94-97.

31 Su Y, Wang X, Zhu WG: DNA methyltransferases: the role in regulation of gene expression and biological processes (in Chinese). Yi Chuan 2009;31:1087-1093.

32 Teodoridis JM, Strathdee G, Brown R: Epigenetic silencing mediated by $\mathrm{CpG}$ island methylation: potential as a therapeutic target and as a biomarker. Drug Resist Updat 2004; 7:267-278.

-33 Baba S, Yamada Y, Hatano Y, Miyazaki Y, Mori H, Shibata T, Hara A: Global DNA hypomethylation suppresses squamous carcinogenesis in the tongue and esophagus. Cancer Sci 2009;100:1186-1191.

-34 Mizuno S, Chijiwa T, Okamura T, Akashi K, Fukumaki Y, Niho Y, Sasaki H: Expression of DNA methyltransferases DNMT1, 3A, and $3 \mathrm{~B}$ in normal hematopoiesis and in acute and chronic myelogenous leukemia. Blood 2001; 97:1172-1179.

-35 Robertson KD, Uzvolgyi E, Liang G, Talmadge C, Sumegi J, Gonzales FA, Jones PA: The human DNA methyltransferases (DNMTs) 1, 3a and 3b: coordinate mRNA expression in normal tissues and overexpression in tumors. Nucleic Acids Res 1999; 27:2291-2298.

36 Barish GD, Yu RT, Karunasiri M, Ocampo CB, Dixon J, Benner C, Dent AL, Tangirala RK, Evans RM: Bcl-6 and NF-kappaB cistromes mediate opposing regulation of the innate immune response. Genes Dev 2010; 24:2760-2765.

37 Januchowski R, Prokop J, Jagodzinski PP: Role of epigenetic DNA alterations in the pathogenesis of systemic lupus erythematosus. J Appl Genet 2004;45:237-248.
38 Guimaraes AL, Correia-Silva Jde F, Diniz MG, Xavier GM, Horta MC, Gomez RS: Investigation of functional gene polymorphisms: IL-1B, IL- 6 and TNFA in benign migratory glossitis in Brazilian individuals. J Oral Pathol Med 2007;36:533-537.

39 Guimaraes AL, Correia-Silva Jde F, de Sá AR, Victoria JM, Diniz MG, Costa Fde O, Gomez RS: Investigation of functional gene polymorphisms IL-1beta, IL-6, IL-10 and TNFalpha in individuals with recurrent aphthous stomatitis. Arch Oral Biol 2007;52:268-272.

40 Guimaraes AL, de Sá AR, Victoria JM, de Fatima Correia-Silva J, Gomez MV, Gomez RS: Interleukin-1beta and serotonin transporter gene polymorphisms in burning mouth syndrome patients. J Pain 2006;7: 654-658.

41 Xavier GM, de Sá AR, Guimaraes AL, da Silva TA, Gomez RS: Investigation of functional gene polymorphisms interleukin-1beta, interleukin-6, interleukin-10 and tumor necrosis factor in individuals with oral lichen planus. J Oral Pathol Med 2007;36:476-481.

42 Dan H, Liu W, Zhou Y, Wang J, Chen Q, Zeng $\mathrm{X}$ : Association of interleukin-8 gene polymorphisms and haplotypes with oral lichen planus in a Chinese population. Inflammation 2010;33:76-81.

43 Dutra WO, Moreira PR, Souza PE, Gollob KJ, Gomez RS: Implications of cytokine gene polymorphisms on the orchestration of the immune response: lessons learned from oral diseases. Cytokine Growth Factor Rev 2009; 20:223-232.

44 Liu Z, Wang L, Wang LE, Sturgis EM, Wei Q: Polymorphisms of the DNMT3B gene and risk of squamous cell carcinoma of the head and neck: a case-control study. Cancer Lett 2008;268:158-165.

45 Cebrian A, Pharoah PD, Ahmed S, Ropero S, Fraga MF, Smith PL, Conroy D, Luben R, Perkins B, Easton DF, Dunning AM, Esteller M, Ponder BA: Genetic variants in epigenetic genes and breast cancer risk. Carcinogenesis 2006;27:1661-1669.

46 Jones JS, Amos CI, Pande M, Gu X, Chen J, Campos IM, Wei Q, Rodriguez-Bigas M, Lynch PM, Frazier ML: DNMT3b polymorphism and hereditary nonpolyposis colorectal cancer age of onset. Cancer Epidemiol Biomarkers Prev 2006;15:886-891.

47 Simao Tde A, Simoes GL, Ribeiro FS, Cidade DA, Andreollo NA, Lopes LR, Macedo JM, Acatauassu R, Teixeira AM, Felzenszwalb I, Pinto LF, Albano RM: Lower expression of p14ARF and p16INK4a correlates with higher DNMT3B expression in human oesophageal squamous cell carcinomas. Hum Exp Toxicol 2006;25:515-522.

48 Resende RG, Correia-Silva Jde F, Arao TC, Silva TA, Abreu MH, Bittencourt H, Gomez RS: Investigation of functional IL-10 gene polymorphism and IL-10 levels in acute graft-versus-host disease. J Clin Immunol 2010;30:465-473. 